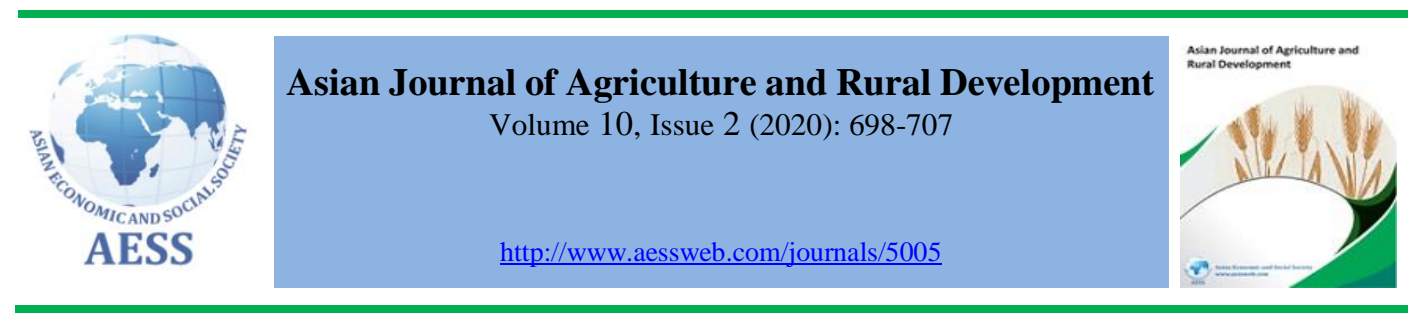

\title{
MULTINOMIAL REGRESSION ANALYSIS OF YAM (DIOSCOREA SPP.) CONSUMERS' PREFERENCES AND VARIETAL DIVERSIFICATION PATTERN IN NIGERIA
}

Felix Odemero

Achoja $^{a}$,

Emmanuel Chukudinife

Enujeke ${ }^{\text {b }}$

Oraye Dicta Ogisi ${ }^{a}$,

Rebecca Tega

Overehirha $^{\text {a }}$

\section{ARTICLE HISTORY:}

Received: 27-Mar-2020

Accepted: $31-\mathrm{Jul}-2020$

Online Available: 10 -Sep-

2020

\section{Keywords:}

Consumer preference,

Yam supply,

Varietal diversification,

Yam farmers' response,

Nigeria a Department of Agricultural Economics and Extension, Faculty of Agriculture, Delta State University, Asaba Campus, Nigeria

${ }^{b}$ Department of Agronomy, Faculty of Agriculture, Delta State

University, Asaba Campus, Nigeria

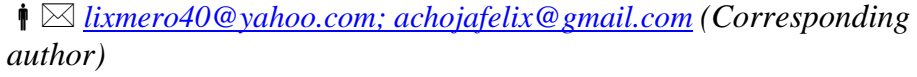

\吕mero40@yahoo.com; achojafelix@gmail.com (Corresponding author)

\section{Contribution/ Originality}

The study empirically established that yam production and consumption preferences are dynamic but predictable behaviors. It is one of the latest studies that applied the economic theories of production, supply, and demand to the analysis of yam production systems, which was a missing gap and has thus expanded the frontier of yam varietal diversification literature.

DOI: 10.18488/journal.ajard.2020.102.698.707

ISSN(P): 2304-1455/ ISSN(E): 2224-4433

How to cite: Felix Odemero Achoja, Emmanuel Chukudinife Enujeke, Oraye Dicta Orisi and Rebecca Tega Overehirha (2020). Multinomial regression analysis of yam (Dioscorea spp.) consumers' preferences and varietal diversification pattern in Nigeria. Asian Journal of Agriculture and Rural Development, 10(2), 698-707. 


\section{INTRODUCTION}

Yam (Dioscorea spp.) is a major source of food for millions of people in the tropical and subtropical areas of the world and especially in West and Central African, where it contributes to the income and food of more than 60 millions of people (Asiedu and Sartie, 2010). In West and Central Africa and the Caribean, yam is one of the most important sources of carbohydrates to many people and is considered as food security crop. The global projection for root and tuber crop foresees an increase in its economic importance through the increase in both the production and consumption (Scott et al., 2000; Alexanderatos and Bruinsma, 2012). Discorea rotundata and Discorea cayenensis (Figure 1 \& Figure 2), respectively, are known as white yam and yellow yam. They are the most valuable and important varieties of yam in West Africa and central Africa ${ }^{1}$.

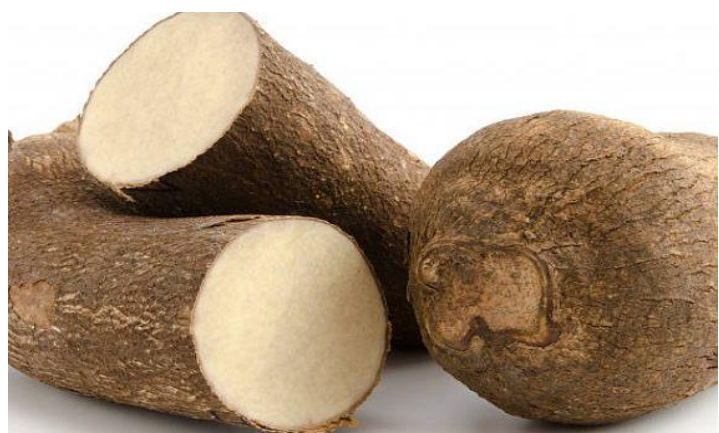

Figure: White yam

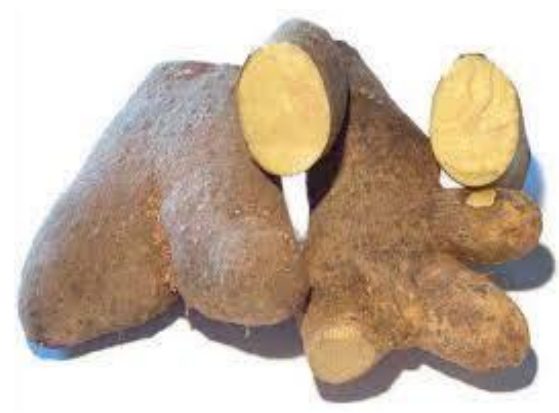

Figure 2: Yellow yam

Despite the nutritious value of yam, little is known as consumers' preference regarding yam characteristics and product quality. However, awareness has been raised that a greater consumers' preference analysis is required for an improved yam production system that can sustain the food security system (Selfa et al., 2008; Rastoin and Ghersi, 2010; Tsolakis et al., 2014).

Yam is the second most important tuber crop in the world after cassava in terms of production (IITA, 2013). It is an important food source in other tropical countries, including East Africa, the Caribbean, South American, India, and Southeast Asia (Okonkwo, 1985). Average yam consumption per capita per day is highest in the Benin Republic (368 kcal), followed by Cote d' Ivoire (342cal), Ghana (296jca1), and Nigeria (258kca1) (IITA, 2009).

Yarn price has been increased, and in recent years due to the strong demand for the crop in Africa, Europe, and the USA, where rapidly growing West Africa migrated, communities still have a big appetite for their traditional preferred staple. Nigeria exported the US \$27.7 million worth of yam to the United States of America in 2011 (Babatunde, 2012), and it is expected that much foreign exchange through yam trade would be realized in the future.

Nigeria is the highest producer of yam with more than 45.004 million metric tons (mmt) annually, with Ghana (7.1 19mmt), Cote d'Ivoire $(5.8 \mathrm{mmt})$, and Cameroon $(0.579 \mathrm{mmt})$. Yam contributes more than 200 dietary calories per day for over 60 million people in Nigeria (Nweke et al., 1991). Yam is also important as a source of pharmaceutical compounds like saponins and sapogenin, which are precursor of cortisone and steroidal hormones (Okonkwo, 1985).

1 Retrieved from https://www.agriculturenigeria.com/research/yam-varieties/ 
The most important species of yam include D. rotundata, D.cayensis, D.dumetorum, D.esculenta, D.bulbifera, D.trifida, D.opposita, D.japonita and D.hispida. Diversified yam farming systems are deemed as an important strategy to address the sustainability challenges of the present-day agriculture, such as economic viability for farmers, environmental soundness, and social acceptability by consumers (Martin et al., 2020). The decision to cultivate diverse yam species may be affected by some consumer-based factors like taste and price variations. Yet studies of varietal diversification in yam farming are limited.

Yam is one of the staple food crops grown in Nigeria. The relevance of yam as a staple foodstuff in Nigeria cannot be overlooked. Among the numerous problems, the average Nigerian yam farmer is the non-availability of steady demand and varietal preference. Moreover, the study tends to analyze the relationship between consumer preference and supply response for yam varieties. The outcome of this research will enable yam producers to respond rationally to varietal preferences among yam consumers.

Again, the study will be useful to extension personnel to yam varietal consumption preferences and the corresponding varietal diversification responses among producers in the yam production system in Nigeria.

Yam (Dioscorea spp.) has many varieties that exist in the world, but information on the most preferred variety among yam consumers is lacking and overlooked by previous authors. Previous investigations on yam were mainly focused on the production stage to the neglect of post-harvest issues such as marketing, consumer preferences, and associated variables (Ehirim et al., 2007; Aidoo et al., 2012). There is a lack of information on factors that determine consumer's preference for yam varieties in Nigeria. Consumer preference is an important driver of agricultural production intensification, including export response (Achoja et al., 2012). Consumer preference for some yam varieties could therefore stimulate variety-based supply responses and could lead to the extinction of the unpopular varieties. It is, therefore important to investigate whether the supply of yam varieties is market dependent or subsistence dependent in the study area. As it stands, factors that influence the supply of yam, as well as the gap between the demand and supply of yam, have not received adequate research attention in Delta State, Nigeria.

Because of the problem, the major objective of the research was the multinomial regression analysis of yam varietal diversification and associated factors in the yam production system in Nigeria.

The specific objectives of the study were:

i. ascertain the quantity of yam consumed by the household;

ii. assess the quantity of yam supplied by producers;

iv. determine consumer's preference for yam varieties; and

iv. evaluate the factors that influence yam varietal diversification among yam farmers.

The following hypothesis was formulated and tested to guide the study.

$\mathrm{H}_{0} 1$ : Consumer's preference does not significantly determine the varietal diversification of yam farmers.

\section{MATERIALS AND METHODS}

\subsection{Study area}

The research was carried out in Delta State, Nigeria. The area was chosen for the study because there are many yam producers and consumers. It covers an area of $818 \mathrm{~km} / \mathrm{square}$; it has a population of 320,687 as of the 2006 population census. The major occupation of these people is 
farming with crops cultivated as cassava, yam, okro, oil palm. The communities studied were Agbarho, Agbarha, Evwreni, Ogor, Orogun, Uwheru, and Ughelli.

\subsection{Sampling technique, sample size and data collection techniques}

A simple random sampling method was used to select (24) twenty-four Respondents from the five clans making the total sample size of one hundred and twenty (120) respondents in the following manner. Out of the seven clans in the local government area, five clans were randomly selected. In each clan, two communities were randomly selected from making a total of ten that were selected for the study. In each community, ten yam consumers and ten yam producers (supplies) were randomly selected, making a total of 100 yam consumers and 100 yam producers. Hence a total of 200 respondents were selected for the study. Primary data were collected with the aid of a structured questionnaire and interview schedule.

\subsection{Data analytical techniques}

Descriptive (mean, percentage, table, charts) and inferential statistics (multiple regression) were employed to analyze collected data. Consumer preference for yam varieties was achieved using frequency distribution tables and charts. Factors that influence consumer preference for yam varieties were analyzed using demand function derived from a multiple regression model. The factors that influence the supply response of yam varieties were evaluated using the supply function derived from the multiple regression model.

\subsection{Model specification}

The supply response model for yam is explicitly specified of yam supply response model was specified as:

Multinomial regression model for Yam Consumption preference

$$
Y P=\beta_{0}+\beta_{1} I n c+\beta_{2} V+\beta_{3} S+\beta_{4} H T+e i
$$

Where:

$\mathrm{YP}=$ Yam preference (variety preferred by household head)

Inc $=$ Income of household

$\mathrm{V}=$ Variety of yam

$\mathrm{S}=$ Seasonal influence

HT $=$ Household taste

$\beta_{0}=$ intercept term /constant

$\beta_{1}-\beta_{4}=$ Coefficient of parameter estimates

Multinomial regression model for Yam varietal diversification (supply)

$$
Y S=\beta_{0}+\beta_{1} P+\beta_{2} S+\beta_{3} I N C+\beta_{4} V+e i
$$

Where:

YS = Quantity of yam varieties supplied

$\mathrm{P}=$ Price per unit of yam

$\mathrm{S}=$ Seasonality of yam supply

INC = income earned from yam supply

$\mathrm{V}=$ consumers' preference for yam varieties

$\beta_{0}=$ intercept term/constant

$\beta_{1}-\beta_{4}=$ Coefficient of parameter estimates

$\mathrm{ei}=$ Error term

The gap or difference between yam supply and demand was determined by using t-statistics. 


$$
\begin{array}{r}
T-\text { Test }=Q S-Q D \\
\sqrt{\frac{Q S^{2}}{N S}+\frac{Q D^{2}}{N D}}
\end{array}
$$

Where:

QS = Quantity of yam supplied $(\mathrm{kg})$

$\mathrm{QD}=$ Quantity of yam demand $(\mathrm{kg})$

$\mathrm{QS}^{2}=$ Variance of yam supplied $(\mathrm{kg})$

$\mathrm{QD}^{2}=$ Variance of yam demanded $(\mathrm{kg})$

NS and ND = Numbers of observation for yam supply and demand respectively $(\mathrm{kg})$.

\section{RESULTS AND DISCUSSION}

In Table 1, the mean and standard deviation of yam demand and supply are presented. The mean value of the supply of yarn was $505.34 \mathrm{~kg}$ with a standard deviation of 790.17 and yam demand has a mean value of $14.56 \mathrm{~kg}$ with a standard deviation of 6.612 . The t-value is 6.210 . This result implies that there is a significant difference between the yam demand and supply is greater than $\mathrm{T}$ stat. $(\mathrm{P}<0.05)$.

Table 1: Statistical analysis of yam demand and supply gap during peak season

\begin{tabular}{lccccc}
\hline Variables & Mean & $\begin{array}{c}\text { Standard } \\
\text { deviation }\end{array}$ & t-cal & P-value & Remark \\
\hline Yam supply & 505.34 & 790.17 & 6.210 & 0.000 & Significant \\
Yam demand & 14.86 & 6.612 & t-cal & P-value & \\
\hline
\end{tabular}

Table 2 shows the distribution of consumer preference for yam variety consumed. The result indicates that $71 \%$ of the respondents preferred to consume white yam (Dioscorea rotundata), water yam (Dioscorea alata) (16\%), and yellow yam (Dioscorea cayenensis) (13\%). This finding implies that the scale of preference of yam consumers is biased towards white yam followed by water yam and yellow yam. Other varieties of yam (D.dumetorum, D.esculenta, D.bulbifera, D.trifida, D.opposita, D.japonita and D.hispida) were not visible in the yam market as at the time of this investigation. This finding supports the earlier research report that white yam is the most valuable and important variety of yam in West Africa and central Africa. The result also agrees with the earlier assertion of Chong et al. (2020) that consumers often vary in their preferences for agricultural products.

Table 2: Distribution of consumer preferences for yam varieties

\begin{tabular}{lcc}
\hline Yam variety & Frequency & Percentage \\
\hline White yam & 71 & 71 \\
Water yam & 16 & 16 \\
Yellow yam & 13 & 13 \\
Other varieties & 0 & 0 \\
Total & 100 & $100 \%$ \\
\hline
\end{tabular}

In Table 3, standard coefficients were recorded for a variety of yam consumed (VARTETY), source of income (INCOME), seasonal influence (SEASON), and household size (HOUSEHOLD). In Table 3, standard coefficient values were recorded for variety (VARIETY) of yam, and the quantity of yam consume (CONS) with a coefficient of 0.260 has a strong and positive correlation 
with consumption (CONS). It is an agreement with Mankiw (1998) findings that a variety of yam consumed affect the consumption level of the respondents. It also showed that the relationship between the varieties produced and consumption is strong and positive.

Table 3: Multinomial regression results of factors that influence consumer preference for yam varieties

\begin{tabular}{lccc}
\hline Variables & Coefficient & t-value & P-value \\
\hline (Constant) & 7.545 & 2.450 & 0.016 \\
Source of income & 0.775 & 0.733 & 0.466 \\
Seasonal influence & 0.446 & 0.398 & 0.691 \\
Household taste & 1.107 & 6.313 & $0.000^{* *}$ \\
\hline
\end{tabular}

$\mathrm{R}^{2}=30 \%, \mathrm{R}^{2}$ (adjusted) $=27 \%, \mathrm{~F}$. Value $=10.229$

** $=$ Significant at $1 \%$

The result in Table 3 shows that the $\mathrm{R}^{2}$ value is $30 \%$. It implies that $30 \%$ of the variation in consumers' preferences for yam varieties was due to source of income, seasonality, and household taste. The seemingly low $\mathrm{R}^{2}$ value was possibly due to qualitative responses used for the study.

The standard coefficient value was recorded for income source (INCOME) and consumption with a coefficient of (0.775), which has a strong and positive correlation with yam consumers' preference. It shows that the relationship between sources of income and consumption level is strong and positive. The p-value for the source of income (INCOME) is (0.466), which revealed that there is no significant relationship between consumption level and source of income because the t-stat is greater than (0.05)5\% significant level and less than $95 \%$ confidence level. Thus the null hypothesis is accepted that the socio-economic characteristics of respondents significantly affect the consumer preference level of yam variety in the study area. This result corroborates Nimoh et al. (2012), who reported that consumer characteristics tend to influence consumer preferences significantly.

In Table 3, the standard coefficient was recorded for seasonal influence (SESONAL) and consumption level with a coefficient of 0.446 , which has a strong and positive correlation with consumption level. It reveals that the relationship between season and consumption strong and positive. The $\mathrm{p}$-value for seasonal influence is $(0.69>0.05)$ which reveals that there is no significant relationship between seasonal influence and yam consumption because the p-value is greater than 0.05 significant level less than the $95 \%$ confidence level. We thereby accept the null hypothesis states the socio-economic characteristics o respondents of a variety of yam demand and supply significantly affect the consumption level of the demand and supply response of yam variety. The finding is in line with the findings of Singh (1991) that due to the perishable nature of agricultural products and their consumption was recorded to be more in their season.

In Table 3, the standard coefficients were records for 'households' taste (HOUSHOLD) and consumption (CONS) with a coefficient of 1.107, which has a strong and positive correlation with consumption level. It revealed that the relationship between household size and consumption is strong and positive. The p-value for household size (HOUSEHOLD) is $(0.000<0.05) 5 \%$, which revealed that there is a significant difference between households consumption because the $\mathrm{p}$-value is less than (0.05)5\% significant level thus, the alternate hypothesis is accepted that there is a significant difference between yam consumption yam supply during peak season.

A $1 \%$ change in consumer preference for a yam variety will translate to a $334 \%$ increase in the yam variety supply. The marginal elasticity $>1$ (elastic). This implies that yam producers are responding positively and significantly to consumer preference at a more than proportionate rate. The reason for this finding could be attributed to the fact that yam producers can satisfy the different 
consumers' preferences adequately. This finding agrees with Endrizzi et al. (2014), who reported that preference mapping is important in determining the differences in consumer perception.

Not all yam varieties produced, especially water yam, flow into the market; some are consumed by producing households. Ovharhe et al. (2020) has reported that in Nigeria, some varieties of yam are a common component of backyard farming, mainly produced for household consumption. As a result, only a portion of total yam produced flows into the market. The finding of this study can further be attributed to the shortage of some yam varieties like water yam and yellow yam in the market. This finding agrees with Thomas (1995), who earlier reported that the supply of yam is not at equilibrium with consumer demand.

In Table 4, the standard coefficient value was recorded for income earn (1NCOME), price influence on yam supply (PRICE), varietal influence preference on yam (VARIETY), and seasonal influence on the consumption of yam (SEASON).

Table 4: Multinomial regression result of factors that influences varietal diversification (supply) of yam farmers

\begin{tabular}{|c|c|c|c|c|}
\hline Model & Coefficient & Standard error & t-cal & $\begin{array}{c}\text { P-Value (Significant } \\
\text { level) }\end{array}$ \\
\hline (Constant) & 129.496 & 224.822 & 0.576 & 0.566 \\
\hline Income earn from sales of yam & 0.002 & 0.001 & 2.922 & $0.004 * *$ \\
\hline $\begin{array}{l}\text { Price variation between } \\
\text { difference yam varieties }\end{array}$ & -134.474 & 178.855 & 0.752 & 0.454 \\
\hline $\begin{array}{l}\text { Consumer preference for yam } \\
\text { varieties }\end{array}$ & 334.431 & 152.322 & 2.196 & $0.049 *$ \\
\hline $\begin{array}{l}\text { Seasonal influence on yam } \\
\text { consumption }\end{array}$ & 222.165 & 160.817 & 1.381 & 0.170 \\
\hline
\end{tabular}

Yam Variety Supplied $=\mathrm{f}($ consumer preference for yam varieties $)$

Yam Varietal Supplied $=129.496+334.431 \mathrm{CPY}+$ ei.

$$
\text { t. value }=(0.576) \quad(2.196)^{*}
$$

In Table 4, standard coefficient values were recorded for price influence on yam supply (PRICE) with a coefficient of -0.134 has a strong negative correlation with yam varietal diversification. It all showed that the relationship between price influence of yam supply (PRICE) and yam varietal diversification is weak and negative. The p-value for the price is $(0.454$.), which revealed that there is no significant relationship between yam varietal diversification and price influence of yam supply $(\mathrm{p}<0.05)$; thus, the null hypothesis is accepted that the socio-economic characteristics of the respondents do not significantly affect the supply response to demand for yam variety.

The standard coefficient value was recorded for varied influence preference for yam (VARIETY) and demand to supply response with a coefficient of 0.334 has a strong positive correlation with yam varietal diversification. This is in agreement with Kushwaha and Polycarp (2001) that the variety of yam affects the demand and supply response of the respondents. It also showed that the relationship between variety and profit is strong and positive. The p-value for variety influence of yam supply is $(0.049<0.05)$, which revealed that there is a significant relationship between the variety influence of yam supply and demand response because the $t$-stat is less than $(\mathrm{P}<0.05)$ significant level and greater than the null hypothesis and the accept the alternate hypothesis that the socio-economic characteristics significantly affects the supply response to demand for yam variety in the study area.

In Table 4, the standard coefficient value was recorded for seasonal consumption of yam and yam varietal diversification with a coefficient of 0.222 , which has a strong positive correlation with yam varietal diversification. It shows the relationship between the seasonal consumption of yam and 
yam varietal diversification is strong and positive. The p-value for seasonal consumption (SEASON) is (0.170) 5\% which revealed that there is no significantly relationship between yam varietal diversification and seasonal consumption because $t$-stat is greater than $(0.05) 5 \%$ significant level and less than 95\% confidence level. This alternate hypothesis is accepted that the socioeconomic characteristics significantly affect the supply response to demand for yam variety in the study area. This finding is in agreement with the findings of Umar et al. (2006) that the consumption of yam variety is mostly ascertained by the storage and seasonal influences of the yam.

\section{CONCLUSION}

Yam (Dioscorea spp.) producers' and consumers' preference dynamism is a predictable pattern of behavior that has been understudied and thus lacking in varietal diversification literature. The response of yarn supply to a preference for different varieties of yam was investigated in this study. The following conclusions are drawn from the outcome of the investigation. White yam (Dioscorea rotundata) is the dominant and the most preferred yam variety in the study area. The household taste was the major determining factor of consumer preference for yam varieties. Consumer preference significantly determines varietal diversification (supply) of yam. The result implies that yam producers are responding positively to yam consumers' varietal preferences (market demand pattern) but not at a proportionate rate. We found sufficient evidence to conclude that as long as the supply-end and demand-end of the yam market are active in terms of the unity of preferences for yam varieties, yam production and marketing will be sustained in the future. This study has extended the frontier of existing literature in the area of yam variety by emphasizing the cardinal role played by consumers' preference in determining the varieties and quantity of yam supplied by farmers. Furthermore, house taste and diet patterns as elements of the societal value system turned out to be an important variable that influences consumers' preference behavior patterns towards yam varieties.

Based on the findings of this study, the following recommendations were proffered:

1. Yam farmers and marketers are advised to scale-up their supply to satisfy the increasing demand for white yam.

2. Farmers in the level of supply of yam should be supported to produce more yam varieties in response to the varietal demand pattern of the yam market.

3. The research and development (R\&D) institutions should research the alternative industrial uses of other yam varieties to expand their value chains and thus stimulate more demand and relevance. It will prevent their extinction from the yam production system in the future.

\footnotetext{
Funding: There was no specific financial support for this study.

Competing Interests: The authors declare that there is no competing interest.

Contributors/Acknowledgments: The authors would like to thank the yam growers in the communities that participated in the study for providing them with relevant information. The appreciation is also extended to the field enumerators for the excellent job.

Views and opinions expressed in this study are the views and opinions of the authors; the Asian Journal of Agriculture and Rural Development shall not be responsible or answerable for any loss, damage or liability, etc. caused in relation to/arising out of the use of the content.
}

\section{References}

Achoja, F. O., Idoge, D. E., Ukwuaba, S. I., \& Esowhode, A. E. (2012). Determinants of export-led cassava production intensification among small-holder farmers in delta state, Nigeria. Asian Journal of Agriculture and Rural Development, 2(2), 142-148. 
Aidoo, R., Nimoh, F., John-Eudes, A. B., Ohene-Yankyera, K., Fialor, S. C., Mensah, J. O., \& Abaidoo, R. C. (2012). Estimation of Margins and Efficiency in the Ghanaian Yam Marketing Chain. Asian Journal of Agriculture and Rural Development, 2(2), 226-234.

Alexanderatos, N., \& Bruinsma, J. (2012). World Agriculture towards 2030/2050: The 2012 Revision. ESA Working paper No 12-03 1-147. Agricultural development economics division, FAO united States.

Asiedu, R., \& Sartie, A. (2010). Crops that feed the world 1. Yams for Income and Food Security, 2(203), 315.

Babatunde, J. (2012). Yam improvement for income and security in West Africa (YIIFSWA) product. Vanguard April 2012. https://www.agriculturenigeria.com/research/yamvarieties/.

Chong, F. S., O’Sullivan, M. G., Kerry, J. P., Moloney, A. P., Methven, L., Gordon, A. W., Terence Hagan, T. D. J., \& Farmer, L. J. (2020). Understanding consumer liking of beef using hierarchical cluster analysis and external preference mapping. Journal of the Science of Food and Agriculture, 100, 245-257. doi.org/10.1002/jsfa.10032.

Ehirim, N. C., Onyemauwa, C. S., Ikheloa, E., \& Umezurumba, I. E. (2007). Economics of yam marketing in Umuahia, Abia State, Nigeria. International Journal of Tropical Agriculture and Food Systems, 1(1), 51-56. doi.org/10.4314/ijotafs.v1i1.40886.

Endrizzi, I., Gasperi, F., Rodbotten, M., \& Neas, T. (2014). Interpretation, validation and segmentation of preference mapping models. Food Quality Preferences, 32, 198-209. doi.org/10.1016/j.foodqual.2013.10.002.

IITA (2009). IITA Annual report, international institute of tropical agriculture. Ibadan, Nigeria.

IITA (International Institute of Tropical Agriculture), (2013). Report, achievement, challenges and prospects of yam production in Nigeria. IITA, Ibadan, Nigeria.

Kushwaha, S., \& Polycarp, I. M. (2001). Economics of small scale yam production in Qua'an Pau LGA of Plateau. Pages 69-74, cited in 'The role of agriculture in poverty alleviation', edited by M.M. Abubakar, T.A. Adegbola, and I.S.R. Butswat. Proceedings 34th Annual Conference of Agriculture Society of Nigeria, held 15-19 October, 2001, Abubakar Tafawa Balewa University (ATBU), Bauchi, Nigeria.

Mankiw, N. G. (1998). Principle of economics. Wall Street Journal of Education, 7, 1-73.

Martin, G., Barth, K., Benoit, M., Brock, C., Destruel, M., Dumont, B., Grillot, M., Hubner, S., Marie, M. A., Moerman, M., Mosnier, C., Parsons, D., Ronchi, B., Schanz, L., Steinmetz, L., Werne, S., Winckler, C., \& Primi, R. (2020). Potential of multi-species livestock farming to improve the sustainability of livestock farms: A review. Agricultural Systems $181,102821$.

Nimoh, F., Asuming-Brempong, S., \& Sarpong, D. B. (2012). Consumer preference for processed cowpea products in selected communities of the coastal regions of Ghana. Asian Journal of Agriculture and Rural Development, 2(2), 113-119.

Nweke, F. I., Ugwu, B. O., \& AY, P. (1991). Production cost of yam based cropping in Southern Nigeria. RCMD Research Monograph No. 6, IITA Ibadan Nigeria.

Okonkwo, S. N. C. (1985). The botany of the yam plant and its exploitation in enhanced productivity on the crop. In: Osuji G (ed) Advances in yam Research, Biochemical Society of Nigeria Anambra State University of Technology Enugu, Pp. 3-23.

Ovharhe, O. J., Achoja F. O., Okwuokenye, G. F., \& Joe-James U. O. (2020). Appraisal of backyard farming among households: implications for rural development and food security in Nigeria. Asian Journal of Agriculture and Rural Development, 10(1), 160-170.

Rastoin, J. L., \& Ghersi. (2010). Le System alimentaire mondial. Editions Quae, Versailes.

Scott, G. J., Rosegrant, M. W., \& Ringer, C. (2000). Global projection for root and tuber crop to the year 2020. Food Policy, 25(5), 561-597.

Selfa, T., Jussanme, R. A., \& Winter, M. (2008). Envisioning agricultural sustainability from field to plate: comparing producer and consumer attitudes and practices toward 'environmentally friendly' food and farming in Washington State, USA. Journal of Rural Studies, 24(3), 262-276. 
Singh, S. (1991). Scientific storage and preservation of food grains. Environment \& Ecology, 9, 300-302.

Thomas, F. L. (1995). Agricultural marketing. Hill book.com New York, USA.

Tsolakis, N. K., Keramydas, C. A., Toka, A. K., Sidonia, D. A., \& Lokavou, E. T. (2014). Agrifood supply chain management: A comprehensive hierarchical decision making framework and a critical taxonomy. Biosystems Engineering, 120, 47-64. doi.org/10.1016/j.biosystemseng.2013.10.014.

Umar, A. G, Nwafor, M. S. Likita, S., \& Adoko, S. (2006). The Indigenous yam storage technology and post harvest losses in Nigeria. The Benue State perspective. International Journal of Food and Agricultural Research, 5(2), 113-139. 